\title{
Gender equality in European Union development policy: incorporating women's voices or confirming hierarchies?
}

\author{
Petra Debusscher \\ Department of Political Sciences, Ghent Universty, Belgium
}

\begin{abstract}
This paper examines gender mainstreaming in European Union (EU) development aid towards Sub-Saharan Africa. The aim is to detect how gender (in)equality in Sub-Saharan Africa is framed by the EU by critically assessing the nature and range of the differences between EU and civil society framings of gender (in)equality in Sub-Saharan Africa. Using the method of Critical Frame Analysis, $28 \mathrm{EU}$ programming documents have been analysed and compared to ro civil society texts on gender equality. I conclude that the EU's approach to gender mainstreaming in its development aid towards Sub-Saharan Africa is to a large extent integrationist and predominantly instrumentalist as it is framed as a way of more effectively achieving existing policy goals. The more transformative issues that are put forward by Sub-Saharan African civil society organisations do not fit within the EU's dominant development paradigm that is focused on achieving the Millennium Development Goals and does not significantly challenge gender relations or power structures. The gap between the analysed civil society views and those expressed by the EU can be explained by the EU's reluctance to include in its policy drafting the promotion of gender equality by civil society organisations. Moreover, the gap seems to have both practical and ideological grounds.
\end{abstract}

Key words: gender equality, European Union, Sub-Saharan Africa, development policy, civil society, millennium development goals, critical frame analysis

\section{Introduction}

The EU (Commission plus the 27 member states) is the world's largest donor of development aid, collectively distributing 55 per cent of official development assistance. The EU's oldest relationship in development cooperation is with the African, Caribbean and Pacific (ACP) groups of countries, which since the signing of the Cotonou Agreement in 2000 are organized in this respect through a comprehensive partnership including aid, trade and political dialogue. In its policy documents and public statements, the European Commission frequently stresses gender equality as a goal in its own right; one that has been part of the European integration project since 
its beginning (McCrae, 2010). The Lisbon Treaty considers "equality between women and men" among the EU's core values and objectives (Article 2 TEU), which should be integrated into all operations and policies. Since the nineties the EU has adopted a range of high-level policy documents' confirming that gender is a cross-cutting issue that has to be mainstreamed in all areas of development and into all programs and projects at regional and national levels. In the European Consensus on Development, the EU explicitly articulates gender equality as one of the five essential principles of development cooperation, and in its 2010 Gender and Development Work Plan it stresses that it "has been increasingly active in promoting gender equality in its external action" (European Commission, 2010: 3). Given the growing importance of gender equality across a broad spectrum of EU policy domains, including external action, it is not surprising that some authors have singled out the EU from among other international organisations for its support of gender equality (Debusscher \& True, 2009). But the question arises as to what kind of gender equality goals have been promoted in EU development policy. Over the decades, EU-African relations have changed profoundly because former colonies gained both their independence and a voice in bi-regional policy development. The legitimacy and effectiveness of old policy paradigms were contested by African governments, nongovernmental and inter-governmental organisations. The position of women is one of the issues which should have undergone a paradigmatic change, from a marginal, conservative approach called Women in Development to Gender and Development or gender mainstreaming, a wide-ranging transformative approach that includes the voices of African women and their organisations.

This paper critically examines gender mainstreaming in European Union development aid towards Sub-Saharan Africa and assesses the nature and range of the differences and similarities between EU and civil society framings of gender (in)equality in SubSaharan Africa using the method of Critical Frame Analysis. In particular I look at the framing of gender (in)equality in Sub-Saharan Africa and at the genderedness of these frames. Before delving into the analysis I will sketch the development of gender equality in EU-ACP development policy, discuss the concept of gender mainstreaming and outline the data-set. In the concluding part I will summarize the findings and reflect on why the frames of these actors overlap or diverge, and what the consequences are.

Including the 1995 Council of Ministers Resolution on Integrating Gender Issues in Development Cooperation; the 1998 Council of Ministers Regulation on Integrating Gender Issues in Development Cooperation; the 2000 European Commission Communication on the European Community's Development Policy; the 20or European Commission Communication on the Programme of Action for the Mainstreaming of Gender Equality in Community Development Cooperation; the 2004 European Parliament and Council Regulation on Promoting Gender Equality in Development Cooperation; the 2006 Joint Statement by the Council and the representatives of the governments of the Member States meeting within the Council, the European Parliament and the Commission on EU Development Policy: 'The European Consensus'; the 2007 European Commission Communication on Gender Equality and Women Empowerment in Development Cooperation and the 20ro European Commission Staff Working Document 'EU Plan of Action on Gender Equality and Women's Empowerment in Development 2010-2015'. 


\section{Gender in EU-ACP development policy}

In EU development cooperation with sub-Saharan Africa the first references to women's rights are found in the Third Lomé Convention signed in 1984 with 79 African, Caribbean and Pacific countries (ACP). It states that "co-operation shall support the ACP States" efforts aimed at enhancing the work of women, improving their living conditions, expanding their role and promoting their status in the production and development process" in view "of the arduous nature of their tasks" (ACP-EEC, 1984: Article 123). The recognition of women was still low-key and included a few socio-economic sectors only (health, training and production) (Lister, 2006). This 'Women in Development' approach often reinforced women's secondary roles and focussed "on what development could get from women" rather than on social justice and how development policies could be transformed to be more gender equal (True, 2010: 19I). The Women in Development approach was increasingly criticised by feminist development scholars and activists, especially from the South, who questioned its focus on economic efficiency gains and pointed out that its narrow focus on women was ineffective as it ignored the underlying societal problems, namely unequal gender relations (Moser, 1993). The Fourth Lomé Convention, signed in 1989 , contained a full subsection on women. Article 287 , which stated that projects and programmes should take into account "cultural, social, gender and environmental aspects", could be seen as a first step towards a somehow broader equality agenda including the strategy of gender mainstreaming (ACP-EEC, 1989).

Following the 1995 United Nations (UN) Beijing Conference, the international community officially replaced the conservative Women in Development paradigm by a more transformative Gender and Development paradigm and embraced the strategy of gender mainstreaming. The Gender and Development paradigm drew from socialist feminist theories of women's subordination and "sought to develop a theory of gender... informed by gender analysis of world economy" and taking into account women's unpaid reproductive work (True, 20I0: I9I). The new paradigm was considered innovative; it focuses on gender without dislodging women as the central subject, as it recognises that improving women's status requires analysis of the relations between women and men. Instead of privileging "the efficiency gains" that could be gained from "utilizing women's labour for economic development, the analysis focused on gender power relations and bottom-up development involving women's NGOs and participatory planning." (True, 2010: I9I). The concept of 'gender mainstreaming' represented a further development and can be seen as a "more institutionally palatable version" of the Gender and Development paradigm (True, 2010: I9I). Gender mainstreaming would widen the scope from add-on, small-scale projects for women, to the integration of a gender equality perspective into all policies (JohnssonLatham, 2010).

In 1997, the commitment to gender mainstreaming was written into the EU Treaty, stating that "in all the activities [...] the Community shall aim to eliminate inequalities and to promote equality between men and women" (EU, I997: Article 2). Accordingly, the EU has adopted a range of high-level policy documents confirming that gender has to be mainstreamed in all areas of development and into all programmes and projects at 
regional and national levels. Gender mainstreaming was also explicitly taken up in EUAfrican development policy when, in 2000 , the Lomé Convention was replaced by a new Partnership Agreement between the ACP states and the EU, signed in Cotonou. In many respects, the Cotonou Agreement meant a break with the past: gender equality and gender mainstreaming were made priorities and references to civil society participation and the promotion of women's organisations were included in the Agreement. In Article I for example, it is stated that "systematic account shall be taken of the situation of women and gender issues in all areas - political, economic and social" (ACP-EC, 2000).

\section{Gender mainstreaming: the concept}

As the ultimate aim of gender mainstreaming is to alter discriminatory gender norms, structures and practices in society, it is generally regarded as a transformative approach. However, some approaches to gender mainstreaming are more transformative than others. In the debate about the usage and meaning of gender mainstreaming, Jahan (1995) has identified two approaches: an 'agenda-setting' and an 'integrationist' approach. Prerequisite to a transformative development agenda is an 'agenda-setting approach' towards gender mainstreaming, where women or organizations affected by development interventions have a voice in " shap[ing] the objectives, priorities and strategies of development." (Jahan, 1995: 127). Gender mainstreaming as a "strategy [that] aims at a fundamental transformation" (Verloo, 200r: 3) is different from an 'integrationist approach' which addresses "gender issues within existing paradigms" (Beveridge \& Nott, 2002: 300) and reduces "gender mainstreaming as a way of more effectively achieving existing policy goals." (Walby, 2005: 323). A transformative agenda not only "implies the transformation and reorientation of existing policy paradigms" (Walby, 2005: 323), but also "requires efforts to create constituencies that demand change" (Mukhopadhyay, 2007: 137). This condition is reflected in Naila Kabeer's idea of transformative agency, which entails the "greater ability on the part of poor women to question, analyse and act on the structures of patriarchal constraint in their lives" (Kabeer, 2005: 15). Mukhopadhyay shows how mainstreaming gender without including women's voices leads to a de-contextualisation of policies and the ending of initiatives specifically directed towards women, which is detrimental to women's interests in countries where extreme gender segregation requires that women's issues be addressed separately (Mukhopadhyay, 2007). The inclusion of different civil society perspectives gives "women's groups the possibility of gaining ownership over processes of policy making on issues of concern for them" and "increases the possibility that policy-makers become more aware of their own biases" (Krizsan \& Lombardo, 2012: 9-10). Therefore, the concept of gender mainstreaming as a transformative strategy involves the naming and challenging of existing gender and power relations through policy interventions wherein formerly disempowered women and their organisations participate in questioning, analysing and acting upon the gendered world. Of course this does not mean that civil society organisations and women's groups can be seen automatically as inherently democratic (Vervisch, 2006) nor that participatory processes are the only way of ensuring qualitative 
gender equality policies (Krizsan \& Lombardo, 2012). However empirical research has shown "that policies developed with the participation of civil society tend to be framed in more transformative ways" as this "increases the possibility that policy-makers become more aware of their own biases" (Krizsan \& Lombardo, 2012: 9).

\section{Dataset and methods}

In order to examine the integration of gender equality in EU development policy towards sub-Saharan Africa, I have analysed Country Strategy Papers (CSPs) and National Indicative Programmes (NIPs). CSPs and NIPs are bilateral agreements between the EU and the government of the partner country. CSPs consist of three parts: the country analysis, which depicts the social, political, economic, trade and environmental situation; the overview of past and on-going development aid; and the response strategy, which establishes the development priorities in order to tackle the problems described in the country analysis. The NIP makes the priorities from the response strategy operational by outlining the specific programmes in selected focal and non-focal sectors and adds timetables, budgets and measurement indicators.

In theory, the drafting process of these agreements is initiated in the respective countries. The National Authorising Office (the unit dealing with the programming of EU Aid, mostly located in the Ministry of Finance or Economic Affairs and Planning), along with the EU Delegation, draws up a first draft of the CSP, including an indication of the main priorities for EU action in the country. This draft is then presented to the European Commission (notably the country desk officer in Brussels), which produces a second draft, which is in turn circulated to the National Authorizing Office for another round of consultations. Once redrafted, the CSP is sent back to the Commission for final adoption (Cotonou Working Group, 2006). According to Article 4 of the Cotonou Agreement, civil society representatives should be involved in this programming process.

I have analysed the CSPs and NIPs of I4 countries: Botswana, Ethiopia, Gambia, Ghana, Lesotho, Mauritius, Namibia, Rwanda, Seychelles, Sierra Leone, South Africa, Swaziland, Tanzania and Zambia. ${ }^{2}$ In total I have analysed 28 CSPs and NIPs: the first generation CSPs and NIPs (2002-2007) from these fourteen countries and the second generation CSPs and NIPs (2008-2013). In addition to analysing EU programming documents I have analysed the views of a selection of civil society actors ${ }^{3}$ working on gender equality (Io texts of activist networks and NGOs) to detect possible silences in the CSPs

2 Country Strategy Papers and National Indicative Programmes 2002-2007 and 2008-2013 are available at: http://ec.europa.eu/development/geographical/methodologies/strategypapers_en.cfm and http://ec.europa.eu/development/geographical/methodologies/strategypapersio_en.cfm.

3 I have chosen texts of activist organizations or networks grounded in an "[a]wareness and rejection of patriarchal privilege and control" as well as "an understanding of gender as an important relationship within the broad structure of social relationships of class, race and ethnicity, age and location." (Antrobus, 2011: 391). All organisations and networks have members in several Sub-Saharan African countries to guarantee a wider representation. As the choice of the analysed texts was subject to availability on the internet and in English, the selected documents are only a snapshot of what gender activists in Sub-Saharan Africa might have to say or even of what the selected organisations might have to say. 
and NIPs (what is not said), and to determine the extent to which the approach is convergent with "the substantive objectives of the women's movement" (Jahan, 1995: 127). The selected civil society organisations include the African Feminist Forum (AFF) ${ }^{4}$, the African Women's Development and Communication Network (FEMNET) ${ }^{5}$, Gender-Based Violence Prevention Network (GBVPN) ${ }^{6}$, Gender and Media Southern Africa (GEMSA) Gender Links ${ }^{8}$, JASS Southern Africa ${ }^{9}$, and the Solidarity for African Women's Rights Coalition (SOAWR) ${ }^{10}$. To examine these documents I have used Critical Frame Analysis which is a methodology that builds on social movement theory and was further developed by the MAGEEQ project ${ }^{11}$ to identify how gender equality policies are framed (Verloo, 2005b). From this methodology I selected two aspects which are of importance to answer the research question. First, what are the problems and solutions relating to gender (in)equality put forward and how are they framed? Second, how gendered are these problems and solutions. I start by examining how gender (in)equality is put forward in the CSPs and NIPs and contrast this with the views that come forward in a set of civil society documents on the same topics to detect possible silences in EU programming. A transformative frame would constitute a broad conception of gender inequality problems and solutions (in

The AFF is a biennial conference hosted by the African Women's Development Fund that brings together African feminist activists to deliberate on issues of key concern to the African women's movement. The first conference took place in 2006 in Accra, Ghana. See http://www.africanfeministforum.com/

FEMNET is a membership-based pan-African Network set up in 1988 by national women's networks to co-ordinate African preparations for the Fourth World Conference on Women in Beijing in 1995. It aims to advance African women's development, equality and other human rights and operates through a Regional Secretariat based in Nairobi Kenya and National Focal Point organisations most of which are national women's networks, consortia or umbrella organizations spread out in over 30 countries in Africa. See: http://femnet.co/index.php/en/

6 The GBV Prevention Network consists of activists and practitioners committed to preventing gender-based violence in the Horn, East and Southern Africa. It was founded during a Regional Dialogue hosted by Raising Voices and UN-Habitat's Safer Cities Program in 2003. Today it has over 380 members (both women and men, survivors of violence, witnesses to violence) from 24 different countries, including organizations, individuals, academics, social justice activists, development workers, feminists, donors, and so on (from small, rural, community-based organizations, national organizations, international organizations, foundations, government institutions, universities and the UN) See: http://www.preventgbvafrica.org/

7 The GEMSA network is an umbrella organisation of individuals and institutions who work to promote gender equality in and through the media. The network has its roots in the Southern African Gender and Media Summit attended by 184 participants from around the region in 2004. See: http://www.gemsa.org.za/page.php?p_id=I

Gender Links is a Southern African NGO, headquartered in Johannesburg, South Africa that promotes gender equality and justice across the fifteen countries of the region. It was founded in March $200 \mathrm{r}$. See: http://www.genderlinks.org.za/

9 JASSSouthernAfricaisamovement-buildingorganisation thatanalysesandchallengeswomen'sinequalitythrough the lens of power and HIV/AIDS. JASS Southern Africa is a part of JASS which is an international feminist organization founded in 2003 as a community of practice by activists, popular educators, and scholars from 13 countries. See: http://www.justassociates.org/en/jass-southern-africa.

The Solidarity for African Women's Rights is a coalition of 36 civil society organizations across the continent working towards the promotion of the Protocol to the African Charter on the Rights of Women in Africa and to urge all African leaders to safeguard the rights of women through ratification and implementation of the Protocol. See: http://www.soawr.org/en/ 
terms of policy domains and issue areas) as well as a long-term agenda to tackle deeply rooted societal norms and practices within which inequalities are embedded (in terms of a deeper content). In a transformative frame gender equality is a goal in itself. This is different from an instrumental framing, which reduces gender mainstreaming to "a way of more effectively achieving existing policy goals" (Walby, 2005: 323) and addresses gender issues within existing development policy paradigms. Next I examine what roles are attributed to men and women in achieving gender equality (genderedness) and I compare this with the roles civil society actors attribute to them. In a transformative strategy gender equality can only be realised if change reaches both women and men and if genffder relations are transformed (Lombardo \& Krizsan, 2012). In this part I look explicitly at references and representations of men and women as well as at the male bias in the development process. The latter refers to the non-recognition of women's work and has been at the core of feminist critiques of the gendered nature of development policy ${ }^{12}$ (Rai, 20II) as (unpaid) work of women is directly related to gender inequality in the organization of intimacy, labour and citizenship (Verloo, 2005b). In the next section I will examine how gender (in)equality in Sub-Saharan Africa is framed by the EU by assessing the nature and range of the differences and similarities between EU and civil society framing of gender (in)equality in Sub-Saharan Africa using the method of Critical Frame Analysis.

\section{Gender equality in EU development policy towards Sub-Saharan Africa Frame}

Gender inequality in sub-Saharan Africa is mainly framed by the EU as a problem of high levels of maternal mortality (I4 CSPs) and lack of access to education (I2 CSPs). Other important frames are the link between gender inequality and poverty (II CSPs), HIV/AIDS (Io CSPs) and gender-based violence ( 9 CSPs). The most frequently mentioned solutions put forward in the NIPs are focused on gender-equal access to education (Io NIPs), supporting civil society organisations that promote women's rights (8 NIPs), reducing HIV/AIDS (7 NIPs), promoting maternal and reproductive health (3 NIPs), integrating gender equality issues in the transport sector ( 3 NIPs) and employment (2 NIPs). Two important frames can be detected in these solutions: a major MDG frame and a minor economic growth frame. First, of the dominant solutions, three out of six are framed within the UN Millennium Development Goals (MDGs). Indeed, "promoting the achievements of the MDGs in Africa" is an important EU objective and supporting gender equality is "considered as [a] prerequisite ... for attaining these goals". (European Commission, 2007: 18) In contrast, women's organisations have extensively criticized the MDGs for their narrow scope and minimal agenda as they distract attention from the implementation of the more radical Platform for Action that was agreed upon during the I995 UN Women conference in Beijing (Saith, 2006). Furthermore the MDGs ignore systemic political and power issues concerning gender inequality and do not use a human rights framework, which depicts people as rights holders who can mobilise to demand

I2 See for example Amartya Sen's's critique of "the altruistic family" showing "how women's contributions to the household income are being appropriated without acknowledgement." (Rai, 2011: 15, 20) 
realisation of their rights, rather than as passive recipients of policies (Barton, 2005). This criticism was also voiced in one of the examined civil society texts, where Hilda Tadria, cofounder of the African Women's Development Fund was quoted stating that the MDGs do not go far enough because, "achieving gender equality has more to do with socially accepted cultural beliefs and ideologies that uphold male privilege than with educational or economic goals." (SOAWR, 2005: 28) Second, solutions for gender inequality are often framed economically as a means to create economic growth or reduce poverty. This is, for example, the case in the Ethiopian CSP where it is stated that "women's contribution to household income and production is crucial for fighting poverty" (European Commission, 2002a). In this case, gender equality is used instrumentally to reach the goal of poverty eradication and not as an aim in itself. Such instrumentalist policies serve to maintain traditional gender roles rather than to dismantle gender inequalities. Another example is found in the Mauritian NIP which looks to provide jobs for previously unemployed women. Although this could potentially be an empowering programme, the NIP mainly aims "to ease the burden of unemployment", "increase the skills base available to employers" and "reduce labour and skills mismatches". (European Commission, 2008a: 25-26). Gender equality as an objective in itself is not discussed. Furthermore in the Namibian NIP, gender parity in literacy is among the measurement indicators for the "human resources development" programme. Again gender equality is used instrumentally "to meet the labour market demands and support overall national development goals." (European Commission, 2008b: 6).

Sometimes less evident policy areas are also framed economically. For example in the Botswana NIP "the further fall in HIV/AIDS prevalence ... especially [among young] women" is a crucial aspect of the "human resource development" focal sector with the main aim of reducing poverty "through economic growth" (European Commission, 2008c: 38).

A comparison of EU policy texts with civil society sources shows that the latter are concerned with problems and solutions that do not appear in the CSPs and NIPs. Important silences in the gender inequality diagnosis were the effects of "internationallyimposed neoliberal economic policies" and trade liberalisation on (poor) women (JASS Southern Africa, 2007: 5; 2010; SOAWR, 2005), the exclusion of African women from ICT in daily life (GEMSA, 2006), the use of culture as a smokescreen to curb women's rights (Gender Links, 2010), the domination of old boy networks (JASS Southern Africa, 20I0), the link between HIV/AIDS and poverty (SOAWR, 2005), sexual harassment (Gender Links \& GEMSA, 2009), the role of masculine identities in gender-based violence (GBVPN, 2008; Gender Links \& GEMSA, 2009), the impact of old and "new colonization of the region" (JASS, 2010: 9; AFF, 2006), and sexist images of women that dominate television, newspapers and magazines (GEMSA, 2006; GBVPN, 2008). 
Furthermore, in general civil society actors offer more structural and systemic gender analyses. The gender effects of globalisation for example are a major concern in several of the examined civil society texts. Equally, the system of patriarchy is discussed extensively by civil society, yet it is barely mentioned in the CSPs and NIPs. The analyses of civil society are more systemic-critical and aim at "structural transformation" (AFF, 2006: 6), for example approaching patriarchy explicitly as a changeable system over time and space and stressing its interrelation with systems "of class, race, ethnic, religious and global-imperialism" (AFF, 2006: II).

Important omissions can also be noted in the outlining of solutions. Civil society texts give significantly more attention to "question[ing] the underlying structural inequalities between women and men" (Gender Links, 2010: 3) and discussing ways out of the "deeply rooted societal norms, attitudes and practices" (GBVPN, 2008: 2) that are causing gender inequalities. They propose a " $50 / 50$ campaign" to push for more female political representation (Gender Links, 2010: 6), access to decent jobs (and not just the creation of jobs where women can "dust... the seats") (JASS Southern Africa, 2010: 7), a "new masculinity television campaign" (GBVPN, 2008: 3); education programmes on exemplary women's lives, which can serve as "role model strategies" (FEMNET, 2007, 7), the involvement of local levels in the campaign for women's rights "to have a critical mass of support" (SOAWR, 2005: 9), popularising the feminist charter, which includes translations in as many languages as possible and diffusion through different media (AFF, 2006) and "transforming the ... mindset of both women and men" (GEMSA, 2006: 3). Analysing civil society voices on the topic of gender equality thus reveals that the EU's gender mainstreaming approach is missing important aspects in outlining problems and designing solutions for gender equality and risks losing sight of African realities.

\section{Genderedness}

In EU programming documents women are seen as the main problem holders, since it is mainly women who are mentioned when analysing problems concerning gender inequalities. Men on the other hand, rarely appear in the country analysis and are almost never problematized. When men are mentioned in the analysis, this is mostly numerical (for example percentage of boys/girls in schools) or in a general phrase referring to equality between men and women. Moreover, women are not only seen as the main problem holders in the country analysis, they are also made responsible for the solutions in the NIPs, since men are completely absent from that part of the planning phase and are never explicitly addressed as a target group to solve gender inequalities. The absence of men in the solutions for gender equality implies that women have to catch up with the silent male norm and are made to bear sole responsibility for that. For that matter, this observation of women as a single problem and solution holders is not unique to EU-Sub-Saharan African development policy, but is just as common in internal EU policies on gender equality (Lombardo \& Meier, 2008).

Opinions on the role of men in civil society texts differ from the EU perspective. Some civil society groups see the involvement and commitment of men as crucial in the 
struggle for gender equality (GEMSA, 2006; Gender Links, 2009) while other groups stress the importance of women-only spaces and see challenges in the involvement of men and men's organisations as they fear that they will show "no accountability to women or women's movements" and take a large share of "the shrinking pot of gender equality funding" (JASS Southern Africa, 2010: 6). Another criticism that was voiced in this respect is related to "binary thinking". A view of the world in polarities - such as women versus men, black versus white, old versus young - is becoming more accepted but does not reflect reality and is a limiting factor to finding solutions for equality. Power works dynamically in different moments and a more nuanced understanding is much needed (JASS Southern Africa, 2010: 30).

It is also remarkable that references to the unequal division of unpaid care work between men and women (household tasks and care for family members) are scarce in the diagnoses and absent in the prognoses. In the country analysis, only four out of 28 CSPs mention "women's workload" as an obstacle to gender equality (European Commission, 2002b: 13), although it is widely recognised that "unpaid care work is a major contributing factor to gender inequality and women's poverty" (Budlender, 2004: v; Gammage, 2010). When this topic is mentioned it is depicted as a women's problem only. In most cases women's disproportionally large burden (and the relatively small burden carried by men, in relation to socially necessary but economically invisible care work are left out of the analysis. This neglect is problematic for several reasons. While the silence on this topic implicitly legitimises the unequal division of care work between men and women, it also implies that such work is valueless and ignores its connection to economic growth and development in general. Furthermore, not taking account of women's disproportionally large share in non-market care work in the analysis has implications for the quality of the overall gender analysis. This is because the gender bias in unpaid care work creates a gendered "time and income poverty" (Gammage, 2010) that has a direct impact on several of the issues that are put forward in the EU's programming documents, such as poverty, domestic violence and women's access to (full-time) education and jobs. These links remain invisible in the analysed documents. Care work analyses are notably present in all civil society documents examined. In the examined civil society texts it is clearly stated that stereotypes about caring as 'women's work' should be eradicated and that "men should be involved in care work as they also benefit from [it]" (Gender Links \& GEMSA, 2009: 53). Several groups also want to "transfer... the burden of home-based care from women to government" as "'home-based care' programs have had the effect of exploiting women's devalued care-giving role, while letting governments and the international aid community off the hook for providing basic healthcare" (JASS Southern Africa, 2007: I6, 5).

Also of note when analysing the genderedness of roles in EU development policy documents is that women are often described alongside children, as a 'vulnerable group'. Such language that depicts women as vulnerable and implies that women can be grouped with minors is not only paternalistic, but also particularly disempowering. Some sub-Saharan African civil society groups explicitly resist such an approach stating that "gender 
equality language has been watered down, as the key terms have shifted from 'women' to 'gender' to 'vulnerable groups', thereby losing the essential element of power and injustice at the heart of women's inequality." (JASS Southern Africa, 2010).

\section{Conclusions}

The critical frame analysis reveals a limited agenda in EU-Sub-Saharan African development cooperation, showing that gender is mostly mainstreamed in typical sectors (such as education and health) and that policies are directed at women only. The approach consolidates the status quo since conceptions of masculinity and femininity, as well as the gendered division of care work, are not questioned. Women are consistently singled out, while men are rarely mentioned. In general, men are the silent norm and women are the problem- and solution-holders who have to catch up with the male norm. This conception of women as sole problem- and solution-holders resembles a conservative Women in Development approach and is contradictory to a transformative gender mainstreaming approach, where men and women share responsibility in removing imbalances in society. The approach is integrationist to the extent that apart from the 'usual suspects' gender issues have been included in a few new domains. Furthermore, the approach remains predominately instrumentalist as gender issues are framed within the dominant development policy paradigms and as they are 'sold' as a way of more effectively achieving other policy goals such as the MDGs. As Roggeband argues, the acceptance and implementation of gender mainstreaming depends on the resonance between the framing of gender mainstreaming and the dominant development frames (Roggeband, 2009). For the EU, the MDGs constitute the dominant development frame within which gender mainstreaming has to be realised. Indeed, since 2005 the EU has taken a front position in achieving the MDGs and declared its determination to step up efforts (European Commission, 2005). This course was reconfirmed in 2008 by a Commission Communication stressing "the EU's key role on the international scene and its commitment to the MDGs" (European Commission, 2008b: 3). Although "the more optimistic readings of the MGDs" have stressed their contribution "to 'en-gendering' the global development agenda" (Chant, 2007: 10), feminists around the world have criticised the MDGs for their narrow scope and minimal agenda as they barely represent "women's concerns with gender-based and sexualized violence, reproductive health and rights, reproductive work and other issues that manifest gender inequality and injustice." (Kabeer, 2005; Barton, 2005; Mukhopadhyay, 2007; Chant, 2007; Visvanathan et al., 20II). In their view, the problem of gender inequality is constructed as a technical and depoliticised issue. Also, the emphasis is on girls' rather than women's voices and rights and "far-reaching but controversial areas" such as land rights, male violence and sexual and reproductive rights are ignored (Johnsson-Latham, 2010: 44). Feminists "struggling against the vice of neoliberal theory and policy" even view the MDGs as "a significant step, but in the wrong direction" (Saith, 2006: 1174). Furthermore, the role of men and masculinities has largely been ignored in MDG discourses. Olowu argues that the conceptualisation of the MDGs was flawed from the start as it does not tackle systems 
of patriarchy and constructions of masculinities and femininities. He argues that effective efforts to combat gender inequality in Sub-Saharan Africa are doomed to fail unless they move beyond dominant approaches. Only "when women as well as men at the grassroots level are socially empowered to speak for themselves and ... own the gender equality project in such a way that oppressive patriarchal structures of traditional African societies are questioned openly, will a cogent agenda for attaining MDG 3 become realistic in [SubSaharan Africa]." (Olowu, 2012: 104) However, this ownership is exactly what is missing in EU development policy as previous research has shown that civil society working on gender equality is poorly integrated in the programming phase of EU aid (Debusscher, 20II; Debusscher \& van der Vleuten, 2012). The failure of gender mainstreaming and the gap that exists between civil society views on gender (in)equality and EU views can be explained by the reluctance to include sub-Saharan African civil society organisations promoting gender equality in the CSP drafting process. According to the Cotonou Agreement, civil society representatives should be involved in this programming process. Critical observers agree, however, that the drafting process does not allow any "democratic 'ownership'" and that the programming process is "often used as a way of imposing Europe's economic and geostrategic interests upon ACP countries, at the expenses of the populations' actual needs" (CONCORD, 20I0: $\mathrm{I}$ ). Although civil society is called upon to implement policies and some aid is earmarked for supporting civil society that promotes women's rights, the drafting process is not gender mainstreamed. Women's organisations are written about, but they do not write. Women's organisations are called upon to implement policies, but their views are rarely incorporated in the drafting of these policies.

The EU's reluctance to include women's groups in policy drafting seems to have both practical and ideological grounds. On the practical front, interviews ${ }^{13}$ with EU delegation staff and women's organisations have indicated that the exclusion of women's organisations from the drafting process can be attributed to a lack of resources to conduct proper consultations and attract the relevant civil society actors, but also to a disinterest in gender equality issues at the delegation level. Ideologically, the more transformative issues that are put forward by African civil society organisations, such as radically questioning gender relations and power structures, do not fit within the EU's dominant development paradigm, which is focused on achieving the MDGs. Unless the voices of Sub-Saharan civil society are included in EU development policy, the applied gender mainstreaming approach will continue to confirm the existing hierarchies between dominant and alternative development paradigms, between state and non-state actors and ultimately between men and women.

I3 Interviews conducted with EU staff and civil society in Kigali and Monrovia between May and July 2011 . 


\section{Acknowledgements}

I would like to thank The Research Foundation - Flanders (FWO) for the financial support as well as the three anonymous reviewers for their helpful comments on an earlier draft of this article.

\section{References}

African, Caribbean and Pacific Group of States - European Community (2000). 'Partnership Agreement between the Members of the African, Caribbean and Pacific Group of States of the one Part and the European Community and its Member States of the other Part, signed in Cotonou on 23 June 2000', OJ L 317.

— (1984). 'Third ACP-EEC Convention signed at Lomé on 8 December 1984' OJ L 86.

- (1989). 'Fourth ACP-EEC Convention signed at Lomé on 15 December 1989' OJ L 229.

AFF (African Feminist Forum) (2006). Reclaiming our spaces. Executive Summary of the Ist African Feminist Forum, 15-19 November, Accra.

Antrobus, Peggy (201r). 'The global women's movement: an introduction' in Visvanathan, Nalini; Duggan, Lynn; Wiegersma, Nan and Nisonoff Laurie (eds.), The Women, Gender and Development Reader. London: Zed Books.

Arts, Karin (2006). 'Gender in ACP-EU Relations: The Cotonou Agreement', in M. Lister and M. Carbone (eds.) New Pathways in International Development: Gender and Civil Society in EU Policy (Aldershot: Ashgate).

Barton, Carol (2005). 'Where to for women's movements and the MDGs?', Gender and Development, I3(I), 25-35.

Beveridge, Fiona and Nott, Sue (2002). 'Mainstreaming: a case for optimism and cynicism', Feminist Legal Studies, IO(3), 299-331.

Budlender, Debbie (2004). Why Should We Care about Unpaid Care Work?, New York, UNIFEM.

Chant, Sylvia (2007). 'Gender, Cities, and the Millennium Development Goals in the Global South' (New Series Working Paper, Issue 21), London, LSE Gender Institute.

Concord (2010). 'Civil society involvement in the review of the 10th European Development Fund' (CONCORD Cotonou Working Group Briefing paper), February.

Cotonou Working Group (2006). 'EU-ACP relations: Will the EU deliver on its promises? Information on the Programming of EC Aid for African, Caribbean and Pacific (ACP) countries (Briefing by the Cotonou Working Group Aid)', March: (accessed 25 August 2011).true

http://www.eurostep.org/wcm/dmdocuments/Briefing_programming.pdf

Debusscher, Petra (20II) 'Mainstreaming gender in European commission development policy: conservative Europeanness?', Women's Studies International Forum, 34(I): 39-49.

Debusscher Petra and True Jacqui (2009). 'Lobbying the EU for Gender-equal Development' in J. Orbie, and L. Tortell (eds.) The European Union and the Social Dimension of Globalization.

Debusscher Petra and van der Vleuten Anna (2012). 'Mainstreaming gender in European Union development cooperation with sub-Saharan Africa: promising numbers, narrow contents, telling silences', International Development Planning Review, 34(3): 319-338.

- (2002a). Ethiopia - European Community. Country Strategy Paper and National Indicative Programme for the period 2002-2007.

- (2002b). United Republic of Tanzania Country Strategy Paper and National Indicative Programme for the period 200I-2007.

- (2005). Speeding up progress towards the Millennium Development Goals - The European Union's Contribution, $\operatorname{COM(2005)~132,~} 12$ April.

- (2007). Multiannual Indicative Programmes 2007-2013 for South Africa.

- (2008a). Republic of Mauritius Country Strategy Paper and National Indicative Programme for the period 2008-2013. 
- (2008b). Republic of Namibia Indicative Programme for the period 2008-2013.

- (2008c). Republic of Botswana Country Strategy Paper and National Indicative Programme for the period 2008-2013.

- (2008d). 'The EU - a Global Partner for Development - Speeding up Progress Towards the Millennium Development Goals', COM(2008) I77, 9 April.

- (2010). 'EU Plan of Action on Gender Equality and Women's Empowerment in Development 20102015' SEC(2010) 265, 8 March.

- (1997). 'Treaty of Amsterdam Amending the Treaty on European Union, the Treaties Establishing the European Communities and Certain Related Acts', 97/C 340/01, 2 October.

FEMNET (2007). 'FEMNET News. A Quarterly Newsletter of the African Women's Development and Communication Network. September-December 2007. Enhancing African Women's Leadership', African Women's Development and Communication Network.

Gammage, Sarah (2010). 'Time Pressed and Time Poor: Unpaid Household Work in Guatemala', Feminist Economics, I6(3): 79-112.

GBVPN (Gender-based Violence Prevention Network) (2008). Newsletter, 'Perspectives on Prevention', No. 7, April, Kampala, available at:

http://www.preventgbvafrica.org/sites/default/files/newsletter7.pdf (accessed 31 August 2011).

GEMSA (Gender and Media Southern Africa) (2006). Annual Report 2004-2005.

- (Gender and Media Southern Africa) (2009). Regional Report. Making Care Work Count. A Policy Analysis. Johannesburg: GEMSA.

Gender Links (2010). Gender Links' Vision 2020.

Gender Links and GEMSA (2009). (Gender and Media Southern Africa) (Sixteen Days of Activism 2009 Report.)

Jahan, Rounaq (1995). The Elusive Agenda: Mainstreaming Women in Development. London: Zed Books.

JASS Southern Africa (2007). Imagining and Building African Women's Movements. Johannesburg November 19-22, 2007.

- (2010). Building African Women's Movements. Thinkshop JASS Southern Africa. Johannesburg, September 27-28, 2010.

Johnsson-Latham, Gerd (2010). 'Power, privilege and gender as reflected in poverty analysis and development goals', In Chant (ed.), The International Handbook Of Gender And Poverty, pp. 4I-46. Cheltenham: Edward Elgar Publishing.

Kabeer, Naila (2005). 'Gender Equality and Women's Empowerment: A Critical Analysis of the Third Millennium Development Goal', Gender and Development, $13(1): 13-24$.

Krizsan, Andrea and Lombardo, Emanuela (2012). 'The quality of gender equality policies: A discursive approach', European Journal of Women's Studies.

Lombardo, Emanuela and Meier, Petra (2008). 'Framing Gender Equality in the European Union Political Discourse', Social Politics: International Studies in Gender, State and Society, 15(I): I0I-129.

McCrae, Heather (2010). The EU as a Gender Equal Polity: Myths and Realities. Journal of Common Market Studies, 48(1): 155-174.

Moser, Caroline (1993). Gender Planning and Development: Theory, Practice and Training. London: Routledge.

Mukhopadhyay, Maitrayee (2007). "Mainstreaming gender or "streaming" gender away: feminists marooned in the development business', in: Andrea Cornwall, Elizabeth Harrison and Ann Whitehead (eds.), Feminisms in Development: Contradictions, Contestations \& Challenges, pp. 135-149. London: Zed Books.

Olowu, Dejo (2012). 'Gender equality under the Millennium Development Goals: What options for sub-Saharan Africa?' Agenda: Empowering women for gender equity 26(I): 104-111.

Rai, Shirin M. (2011). 'Gender and development: theoretical perspectives' in Visvanathan, Nalini; Duggan, Lynn; Wiegersma, Nan and Nisonoff Laurie (eds.), The Women, Gender and Development Reader, London: Zed Books. 
Roggeband, Conny (2009). 'No inst.unt success... Assessing gender mainstreaming evaluations', paper prepared for the On Track with Gender Report Expert Meeting, 'Taking Stock', The Hague, 28-29 May, 59-72.

Saith, Ashwani (2006). From Universal Values to MDGs: Lost in Translation. Development and Change, 37(6): II67-99.

SOAWR (Solidarity for African Women's Rights Coalition) (2005). 'The protocol to the African Charter on Human and People's Right's on Women's Rights in Africa: from Ratification to the Realization of African Women's Human Rights' Special Issue of Pambazuka News no 222, Oxford: Fahamu.

True, Jacqui (2010). 'Gender Mainstreaming in International Institutions.' In: Laura J. Shepherd (ed.) Gender Matters in Global Politics, London, Routledge.

Verloo, Mieke. (200I). 'Another Velvet Revolution? Gender mainstreaming and the politics of implementation'. IWM Working Paper 5/200I, Vienna.

- (2005a). 'Displacement and Empowerment: Reflections on the Concept and Practice of the Council of Europe Approach to Gender Mainstreaming and Gender Equality' Social Politics: International Studies in Gender, State and Society 12 (3): 344-365.

- (2005b). 'Mainstreaming Gender Equality in Europe: A Critical Frame Analysis', The Greek Review of Social Research, II7(B): II-34.

Vervisch, Thomas (2006). 'De Civiele Maatchappij: Een Nieuwe Partner in een 'Oud' System? Afrika Focus, I9 $(\mathrm{I}-2): 5-42$.

Visvanathan, Nalini; Duggan, Lynn; Wiegersma, Nan and Nisonoff Laurie (20II). The Women, Gender and Development Reader. London: Zed Books.

Walby, Sylvia (2005). 'Gender Mainstreaming : Productive Tensions in Theory and Practice', Social Politics: International Studies in Gender, State and Society 12 (3): 321-343. 